\title{
Defending science education against intelligent design: a call to action
}

\author{
Alan D. Attie, ${ }^{1}$ Elliot Sober, ${ }^{2}$ Ronald L. Numbers, ${ }^{3}$ Richard M. Amasino, ${ }^{1}$ Beth Cox, ${ }^{4}$ \\ Terese Berceau, ${ }^{5}$ Thomas Powell, ${ }^{6}$ and Michael M. Cox ${ }^{1}$
}

\begin{abstract}
${ }^{1}$ Department of Biochemistry, ${ }^{2}$ Department of Philosophy, and ${ }^{3}$ Department of Medical History and Bioethics, University of Wisconsin-Madison, Madison, Wisconsin, USA. ${ }^{4}$ Cox Law Office, Oregon, Wisconsin, USA. ${ }^{5}$ Wisconsin State Legislature, Madison, Wisconsin, USA. ${ }^{6}$ Office of T. Berceau,
\end{abstract} Wisconsin State Legislature, Madison, Wisconsin, USA

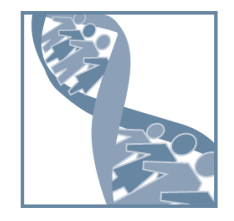

We review here the current political landscape and our own efforts to address the attempts to undermine science education in Wisconsin. To mount an effective response, expertise in evolutionary biology and in the history of the public controversy is useful but not essential. However, entering the fray requires a minimal tool kit of information. Here, we summarize some of the scientific and legal history of this issue and list a series of actions that scientists can take to help facilitate good science education and an improved atmosphere for the scientific enterprise nationally. Finally, we provide some model legislation that has been introduced in Wisconsin to strengthen the teaching of science.

The past decade has seen breathtaking progress in evolutionary biology, thanks largely to the fruits of genome sequencing projects. The molecular footprints linking all life on the planet are now fleshed out in rich detail, and we possess a chronometer of molecular evolution going all the way back to early bacteria. This has sparked a renaissance of interest in speciation, development, and evolutionary aspects of disease susceptibility and resistance. The importance of evolution to biology was properly summarized by White House Science Adviser John Marburger when he said, "Evolution is the cornerstone of modern biology. Period. What else can you say?" (1).

In a parallel universe, a majority of Americans, $54 \%$, do not believe human beings evolved, according to one poll (2). Only $38 \%$ agree with the statement, "human beings evolved from an earlier species" (3). Opposition to evolutionary theory has existed since Darwin. Efforts to eradicate or dilute the teaching of evolution persist throughout the nation despite consistent rejection in the courts. Conservative think tanks, religious fundamentalists, and influential magazines such as National Review continue their attempts to introduce pseudo-science into science classrooms. This movement has gained the support of such prominent politicians as President George W. Bush, Senate Majority Leader Bill Frist, and Senator John McCain. Former House Majority Leader Tom DeLay, a onetime biology major, said, "our school systems teach the children they are nothing but glorified apes who have evolutionized out of some primordial soup of mud" (4). Even the definition of science itself has fallen victim to political attack; the state board of education in Kansas decided that the supernatural may now be taught as science in the classroom. Some have claimed that the challenge to evolution is symptomatic of a broader, more generic attack on science itself (5).

Scientists can no longer afford to let these challenges go unopposed. The wide gap between established facts accepted by scientists and the sentiments sampled in the polls reflects a failure of science education. For this, scientists, particularly those in aca-

Nonstandard abbreviations used: ID, intelligent design.

Conflict of interest: The authors have declared that no conflict of interest exists.

Citation for this article: J. Clin. Invest. 116:1134-1138 (2006). doi:10.1172/JCI28449. demia, must take some responsibility. The remedies are educational and political and must involve scientists and non-scientists. Instituting an effective response does not require large blocks of time, nor need it involve debates with creationists: small actions can have large effects.

\section{The history}

The road to Dover. In 1968, the US Supreme Court unanimously ruled that an Arkansas law banning the teaching of evolution violated the First and Fourteenth Amendments to the Constitution. The Court ruled that the Arkansas law had a religious purpose - namely, to oppose teachings perceived to conflict with the biblical story of creation. Following this defeat, opponents of evolution adopted two strategies. First, they advocated the teaching of creationism as an alternative scientific explanation, along with evolution. Second, they began to adopt scientific jargon to give creationism a veneer of science. Two states, Arkansas and Louisiana, passed laws mandating this "balanced" treatment of evolution and creationism.

This set the stage for the Arkansas trial of 1982 (McLean v. Arkansas Board of Education), which was almost entirely focused on the question "Is creationism science?” Judge William R. Overton stated in his opinion (6) that creationism fails to be a science because it fails to satisfy the following requirements: "(a) it is guided by natural law; (b) it has to be explanatory by reference to natural law; (c) it is testable against the empirical world; (d) its conclusions are tentative, i.e. are not necessarily the final word; and (e) it is falsifiable."

The issue returned to the Supreme Court in 1986-1987. The Court ruled 7-2 in Edwards v. Aguillard that Louisiana's law calling for the balanced treatment of evolution ("evolution-science" and "creation-science") violated the First Amendment "because it lacks a clear secular purpose" and it "impermissibly endorses religion by advancing the religious belief that a supernatural being created humankind" (7).

The creationists once again mutated and adapted. After the Edwards ruling, they set about removing references to God and creationism from their tracts. For example, as revealed at the Dover trial (8), the authors of the intelligent design (ID) text of pandas and people: the central question of biological origins stripped the 
direct mentions of creationism present in early drafts of the text and systematically substituted the novel term "intelligent design" (9).

The evolution of creationism. ID is the contemporary version of an argument that has a long history. It was given a succinct formulation by William Paley in the early 19th century. Modern defenders of the design argument contend that living things are too complex to have evolved by the process of natural selection; rather, their "irreducible complexity" is convincing evidence of the hand of an intelligent designer. ID theory's contemporary advocates, who include Lehigh University biochemistry professor Michael Behe, cite complex systems such as the blood-clotting cascade, the flagellar motor, and the human eye to argue that because these systems would be nonfunctional if even a single component part were excised, they could not have evolved by mutation/natural selection and therefore must have been "intelligently designed." The argument can be boiled down to this: complexity is itself evidence of a designer. In its current version, ID conveniently omits mention of God.

However, ID is not a scientific theory. The premise for the arguments of Behe and other ID proponents is deeply flawed, scientifically and philosophically. Behe assumes that the component parts of irreducibly complex systems never had other functions in older organisms. This is contradicted by scientific evidence. The Dover trial transcripts are illuminating (see "The Dover trial") (8). Under oath, Behe was forced to concede that there are organisms that lack some of the mammalian clotting proteins. Proteins that are present in the flagellar motor have orthologs that are involved in unrelated functions. A recent elegant example of proteins acquiring a new function within a complex system can be seen in a structure that functioned in respiration in fish and later evolved to be part of the mammalian inner ear (10).

ID makes no testable predictions. There is nothing in this concept that allows for scientific investigation of the "designer." It is simply an argument by default; the failure to explain something is said to lend credence to a supernatural explanation. The attempt to promote this as science is deeply misguided. In spite of uncounted hundreds of thousands of scientific studies published in the last 50 years, there are still demonstrable gaps in what we know about the evolution of life on this planet. However, those studies tell us a great deal about how life came to be as it is and now form the foundation of modern biology. ID, by contrast, has produced nothing.

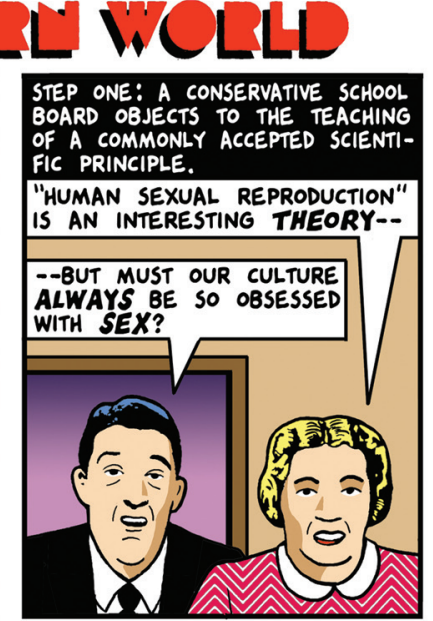

by TOM TOMORROW
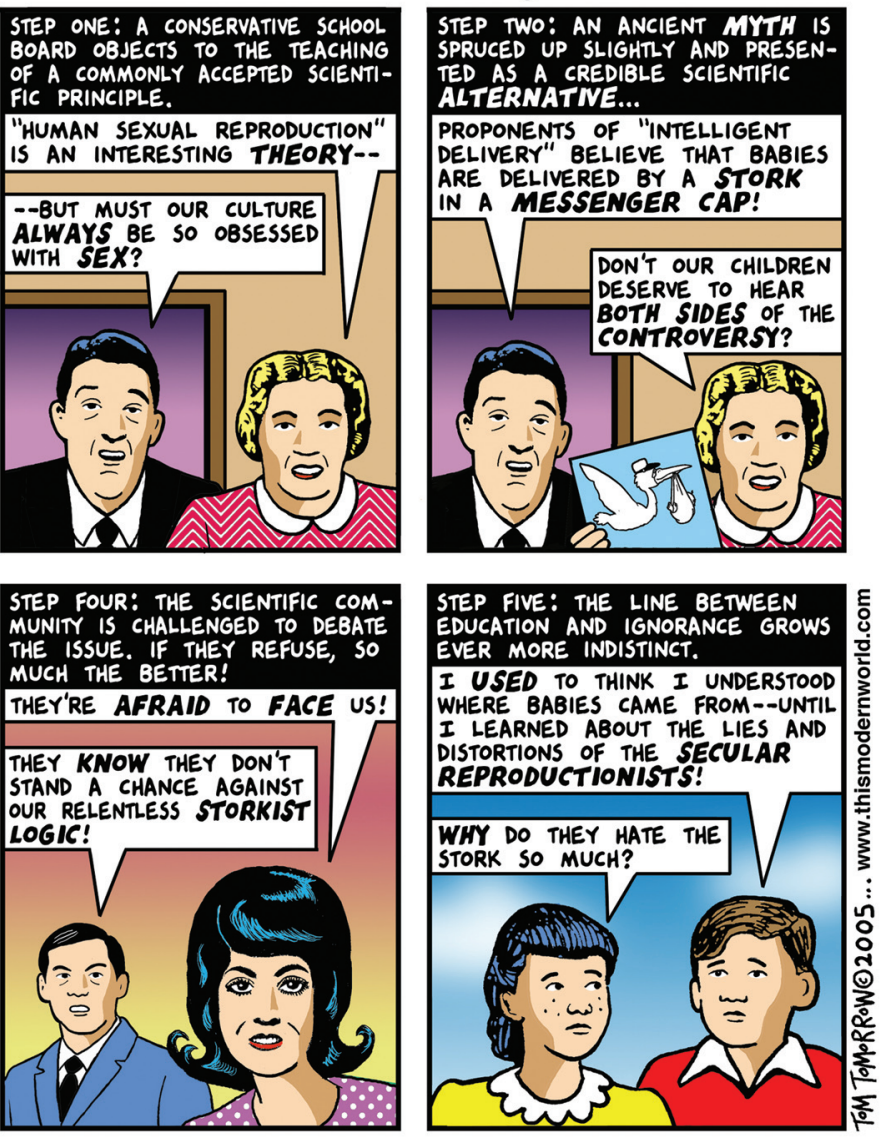

The Discovery Institute. The engine behind the ID movement is the Discovery Institute, founded in 1990 by Bruce K. Chapman. Today, the institute receives more than $\$ 4$ million per year from numerous foundations, most with religious missions. The center's objectives are outlined in its "Wedge Strategy," which was leaked and posted on the Internet (11). The document states that the Discovery Institute "seeks nothing less than the overthrow of materialism and its cultural legacies" and "to replace materialistic explanations with theistic understanding that nature and human beings are created by God." Its goals are to see ID theory as the dominant perspective in science; to see design theory applied in specific fields, including molecular biology, biochemistry, paleontology, physics, and cosmology in the natural sciences and ethics, politics, theology, and philosophy in the humanities; to see its influence in the fine arts; and to see design theory permeate our religious, cultural, moral, and political life.

The Dover decision. In Dover, Pennsylvania, 2005, 11 parents sued to reverse a school board requirement that the following statement be read to students: 'because Darwin's Theory is a theory, it continues to be tested as new evidence is discovered. The Theory is not a fact. Gaps in the Theory exist for which there is no evidence. A theory is defined as a well-tested explanation that unifies a broad range of observations" (Kitzmiller et al. v. Dover Area School District) (12). The required statement referred only to evolution. The third paragraph in the statement read: "Intelligent design is an explanation of the origin of life that differs from Darwin's view. The reference book, Of pandas and people (9), is available for students who 
might be interested in gaining an understanding of what intelligent design actually involves."

In his decision, Judge John E. Jones stated that ID is essentially Paley's argument for the existence of God, with God left unmentioned. In short, ID is a religious doctrine. He noted that Behe "claims that the plausibility argument for ID depends upon the extent to which one believes in the existence of God"; thus, "ID is a religious and not a scientific proposition." He characterized ID as "nothing less than the progeny of creationism." Jones stated that the Dover school statement forces a "false duality" on students by making them choose between God/ID and atheism/science and "singles out the theory of evolution for special treatment, misrepresents its status in the scientific community, causes students to doubt its validity without scientific justification, presents students with a religious alternative masquerading as a scientific theory, directs them to consult a creationist text as though it were a science resource, and instructs students to forego scientific inquiry in the public school classroom and instead to seek out religious instruction elsewhere.”

The Dover case was an important victory for science education. Judge Jones wrote a strongly worded, carefully crafted opinion that should guide future litigation (12). The transcripts of the Dover trial constitute an excellent educational resource, rich in testimony about the nature of science, the evidence for evolution, and the history of deceit in the creationism/ID movement.

\section{Common misrepresentations by ID proponents}

The "teach the controversy" hoax. The ID movement employs a tactic that appeals to the American tradition of "fairness and balance." ID advocates argue that since there is a controversy over evolution, we should "teach the controversy" in public school science classrooms.

The "controversy" is manufactured. Evolutionary biology draws strength from a supporting scientific literature extending across 150 years that includes literally hundreds of thousands of individual papers. Creationists offer no science. In some cases, they have misrepresented science in their efforts to debunk it. For example, in Of pandas and people (9), evolutionary lineages are presented as straight lines linking species, rather than as parts of a tree structure. The incorrect linear model is then used to argue that cytochrome $c$ homology patterns do not conform to evolutionary predictions.

The "just a theory" hoax. Creationists purposefully confuse the two meanings of the word "theory." In common usage, a theory connotes a statement that is tentative or hypothetical. This is the meaning implied in the frequent claim of ID advocates that evolution is "just a theory." However, science uses the term "theory" differently. When substantiated to the degree that evolutionary theory has been, a theory is regarded as a fact. Practicing biologists operate within the rich context of evolutionary theory, and no part of modern biology, including medicine (13), is completely understandable without it. Scientific arguments are not qualified with clauses that allow for a nonevolutionary scenario.

The "fair and balanced" hoax. In the name of "fairness and balance," the media have decided to present "two sides" of this story. For example, a day after the Dover decision, National Public Radio aired a commentary by a Heritage Foundation fellow comparing ID to the Big Bang Theory, predicting that eventually it will be widely accepted by scientists (14). By giving uncritical treatment to "both sides," the media convey to the public the false impression that this is a genuine scientific controversy and that each has a substan- tial body of evidence and convincing argumentation. Journalists should be mindful of the fact that no science supports creationism/ID; 150 years of biological, geological, and physical science supports the modern synthesis of Darwin's theory. The individuals with scientific credentials who support ideas such as ID actually constitute a rather small group, as recently described in a New York Times article (15).

The "persecuted scientist against the establishment" boax. Another plea often articulated by ID proponents is the idea that there is a community of ID scientists undergoing persecution by the science establishment for their revolutionary scientific ideas. A search through PubMed fails to find evidence of their scholarship within the peer-reviewed scientific literature. In the original Wedge document, a key part of the plan to displace evolutionary biology was a program of experimental science and publication of the results. That step has evidently been skipped.

\section{Why ID is a threat to science}

The constant, unanswered assault on evolution is harmful to science and science education. ID and its progeny rely on supernatural explanations of natural phenomena. Yet all of science education and practice rests on the principle that phenomena can be explained only by natural, reproducible, testable forces. Teaching our students otherwise disables the very critical thinking they must have in order to be scientists and is a fundamental distortion of the scientific process. ID is therefore not simply an assault on evolution: it is an assault on science itself.

ID groups have threatened and isolated high school science teachers. Well-organized curricular challenges to local school boards place teachers in the difficult position of arguing against their employers. We have spoken with high school science teachers who feel censored in their efforts to teach the basic principles of science. The legal challenges to local school districts are costly and divert scarce funds away from education into court battles. Although these court battles result in the defeat of ID, they are draining and divisive to local schools.

Finally, the assault on evolution and science threatens our nation's scientific and technological leadership. Political and economic agendas are interfering with the free flow of scientific information. For example, political appointees have ordered scientists at NASA to eliminate references to the Big Bang Theory and to cease to mention the eventual death of the sun billions of years from now in their comments and publications. Other scientists have been cautioned about speaking out on global warming. These actions disrupt the long-standing tradition of public policy based on the consensus of the scientific community.

\section{Our call to action}

Political action in Wisconsin. In 2004, the school board of Grantsburg, Wisconsin, voted to have ID taught as an alternative scientific theory to evolutionary theory. At the University of Wisconsin at Oshkosh, Dean Michael Zimmerman and some colleagues sent a letter to Grantsburg. Letters from scientists and educators from around the state soon reinforced the effort. For example, in late summer 2005 , the Department of Biochemistry at the University of Wisconsin-Madison issued a letter, signed by all 35 active members of the department, urging the school board in Grantsburg to reverse their action. Clergy concerned about the presentation of religious viewpoints as science initiated a parallel effort. More than 10,000 clergy have signed the resulting letter in what is now known as the 


\section{Table 1}

Evolution/creationism/ID resources

\author{
Resource \\ Judge Jones' decision in Kitzmiller v. Dover Area \\ School District \\ Kitzmiller v. Dover Area School District trial transcripts \\ Evolution on the front line (American Association \\ for the Advancement of Science) \\ National Center for Science Education \\ Evolution resources from the National Academies \\ Understanding evolution (University of California-Berkeley) \\ National Science Teachers Association position statement \\ Evolution and the Nature of Science Institutes \\ (Indiana University) \\ The Discovery Institute Wedge Strategy \\ Darwin exhibition (American Museum of Natural History) \\ Kenneth Miller's Evolution Resources (Brown University) \\ PBS evolution site \\ The Talk.Origins archive \\ $\mathrm{K}-12$ resources \\ (University of California Museum of Paleontology) \\ Botanical Society of America statement on evolution
}

\author{
URL \\ http://www.pamd.uscourts.gov/kitzmiller/kitzmiller_342.pdf \\ http://www.aaas.org/news/press_room/evolution/ \\ http://www.ncseweb.org/article.asp?category=2 \\ http://nationalacademies.org/evolution/ \\ http://evolution.berkeley.edu/evolibrary/home.php \\ http://www.nsta.org/positionstatement\&psid=10 \\ http://www.indiana.edu/ ensiweb/ \\ http://www.antievolution.org/features/wedge.html \\ http://www.amnh.org/exhibitions/darwin/ \\ http://www.millerandlevine.com/km/evol/ \\ http://www.pbs.org/wgbh/evolution/ \\ http://www.talkorigins.org/ \\ http://www.ucmp.berkeley.edu/museum/k-12
}

http://www.aclupa.org/legal/legaldocket/intelligentdesigncase/dovertrialtranscripts.htm

http://www.botany.org/newsite/announcements/evolution.php
Clergy Project. The actions of the Grantsburg school board have largely been reversed.

A subsequent op-ed article in the Wisconsin State Journal (16), written by Michael M. Cox, led to contact by Wisconsin Representative Terese Berceau. This conversation led in turn to the formation of an informal advisory committee consisting of scientists, educators, a philosopher of biology, a historian of creationism, and an attorney. This group assisted Representative Berceau in crafting a simple piece of legislation that was introduced in the Wisconsin State Legislature on February 9, 2006. The bill is short and states:

The school board shall ensure that any material presented as science within the school curriculum complies with all of the following: (a) The material is testable as a scientific hypothesis and describes only natural processes. (b) The material is consistent with any description or definition of science adopted by the National Academy of Sciences. (17)

The objective of the bill is simple. Anything presented as science in public schools should be science. Discussion of ID or any other ideology in any other context is not affected, even in the science classroom. The bill is short, but potentially effective. In a state where the Department of Public Instruction guidelines are advisory and have no enforcement mechanism, the bill gives parents a cause of action when inappropriate topics are introduced into a classroom as if they constitute genuine scientific alternatives. If such legislation is enacted, parents in Wisconsin will find it easier to challenge the misrepresentation of science in their schools. The bill also provides support for science teachers who are pressured by school boards or by other groups to eliminate evolution from the curriculum or to teach alternatives that do not belong in the realm of science.

\section{What you can do}

There is a wide range of actions that each scientist can take to facilitate good science education. Our experience has shown repeatedly that every action carries weight and represents a very productive use of time. Some of these require little time; some require a more substantial commitment.

Educate yourself. A few hours with publications available on the websites of the National Academy of Sciences, the American Association for the Advancement of Science, or the National Center for Science Education can help clarify the issues and provide the preparation needed for an effective scientific response to challenges (see Table 1). The decision rendered by Judge Jones in the Dover decision is a particularly excellent resource and is well worth reading in its entirety.

Write letters. Write to legislators and newspapers. Write to school boards considering actions that might undermine science education. Write to government leaders. Respond to comments made by ID proponents wherever they might appear. The letters need not be long, and even one letter every few months will have a large effect. This is an activity that can and should fit into the schedule of every working scientist. Similarly, call in to talk shows featuring pro- or antiscience guests. Every letter written by authors of this paper has elicited a positive response. The ID program consists entirely of public relations efforts. They have had this playing field to themselves for too long.

Organize campus evolution groups. This provides an informal way to husband campus resources in evolutionary biology. Seminar series are useful. Regular meetings to plan special events such as Darwin Day celebrations can serve as outreach exercises.

Organize educational support teams. Scientists can be a compelling resource for teachers in $\mathrm{K}-12$ science programs who are facing pressure from school boards or parents to alter good science curricula in ways that harm students. If a group of such scientists can be organized, individuals need not face unreasonable demands on time, and the group as a whole can provide valuable assistance to educators within the scientists' state.

Participate in outreach activities. Go to local schools and talk to classes about science in general and evolution in particular. Go to school board meetings when appropriate and talk to school board members. Talk to local business groups. 
Organize educational sessions at national and international meetings. Major scientific professional societies should embark on a concerted educational effort, directed both at educating scientists about the problem and arming them for an effective response. Resources also must be made available for science teachers at the $\mathrm{K}-12$ levels. Travel grants, where available, should be concentrated on K-12 teachers to make attendance possible.

Revise textbooks. Scientists engaged in textbook writing should be more cognizant of the need to educate future scientists and science teachers about evolutionary biology. Additional education is required to explain what science is, what defines a scientist, and how the various forms of the scientific method constitute a consistent whole.

Become more effective lobbyists for legislation that improves the atmosphere for science and science funding. We urge scientists in all 50 states to work with their respective legislatures to enact legislation similar to the bill just introduced in the Wisconsin Legislature. This movement should appeal to a widely shared interest to uphold the standards of science education and should transcend political ideology.

Make yourself available at least occasionally as a local resource. Creationists are not deterred by the Dover case. There are troubling situations brewing in almost every state. Scientists should use these new cases as teaching opportunities in their own classrooms and should be willing to testify and support the cause of science education in the courtroom.

Teach. For academic scientists, there is no greater responsibility than the education of our citizenry, and there is no activity that has a greater impact. For too long, educational programs in biology at the college level have neglected to provide a solid grounding in evolutionary biology, despite its central importance. This background has been left to unstandardized mentions in core courses and to upper-level specialized courses that are often not required. A nationwide overhaul of these programs is essential. New introductory courses are needed to provide a background in evolutionary biology at the very beginning of all programs leading to science or science education degrees, and the courses should be required. New lower-level courses for nonmajors, pitched at a level appropriate for students with minimal science background, are needed to expose as many citizens as possible to evolutionary theory and to introduce them to science.

Work with your legislators. Identify legislators who are friends of science and work with them, as we have in Wisconsin, to introduce legislation that supports and strengthens science education.

\footnotetext{
1. University of Colorado Center for Science and Technology Policy Research. 2005. Policy, politics, and science in the White House: conversations with presidential science advisors [transcript of R. Pielke interview with J. Marburger]. http:// sciencepolicy.colorado.edu/scienceadvisors/ marburger_transcript.html.

2. The Pew Forum on Religion \& Public Life. 2005. Public divided on origins of life. http://pewforum. org/surveys/origins/.

3. Harris Interactive Inc. 2005. Nearly Two-thirds of U.S. Adults Believe human beings were created by God. http://www.harrisinteractive.com/ harris_poll/index.asp?PID $=581$.

4. Paul, G.S. 2005. Cross-national correlations of quantifiable societal health with popular religiosity and secularism in the prosperous democracies. Journal of Religion « Society. 7. http://moses.creighton. edu/JRS/2005/2005-11.html.
}

Work with clergy. As Judge Jones indicated, the creationists have fostered a false duality between science and religion. A majority of people do not hold a literal young-earth interpretation of the Bible. The clerical community has a shared interest in keeping science and religion apart. They do not want religion to be presented as science and, like a large block of religious scientists, do not see any conflict between religious belief and evolutionary theory.

\section{Scientific thinking should be part of all education}

Whether in crafting a tax code, making health care decisions, evaluating the economy, exploring the resolution of world conflicts, evidence-based thinking is the best intellectual tool in our possession. In science, controversies are usually temporary. When scientists have divergent hypotheses, they usually agree on the key experiments that will favor one hypothesis over others. This is because there is a consensus that framing questions in a way that is subject to the test of evidence is the most progressive way to advance knowledge and understanding. In an ideal world, such principles ought to be widely embraced. Students should learn the difference between hard evidence and speculation. They should understand the elements of logic and clear, critical thinking. They need to understand how to suspend belief while gathering and evaluating evidence.

As George Orwell observed, "a mere training in ... sciences ... is no guarantee of a humane or skeptical outlook." Yet Orwell advocated universal science education if such an education was structured to focus on "acquiring a method - a method that can be used on any problem that one meets - and not simply piling up a lot of facts" (18).

Within universities, the cultural gap between the sciences and the humanities needs to be bridged. A useful approach is to create courses in critical thinking that combine science and the humanities. Ideally, such courses would include an exploration of contemporary problems from the combined perspectives of the sciences and the humanities, united in the common theme of evidencebased, critical thinking. Given that our universities play a large role in the training of the next generation of government and corporate leadership, investing in a future better guided by evidence-based, critical thinking is the most important investment we can make.

Address correspondence to: Alan Attie, University of WisconsinMadison, Department of Biochemistry, 433 Babcock Drive, Madison, Wisconsin 53706-1544, USA. Phone: (608) 262-1372; Fax: (608) 263-9609; E-mail: attie@biochem.wisc.edu.
5. Mooney, C. 2005. The republican war on science. Basic Books. Cambridge, Massachusetts, USA. 342 pp.

6. Overton, W.R. 1982. McLean v. Arkansas Board of Edu cation [decision]. The Talk.Origins Archive. http:// www.talkorigins.org/faqs/mclean-v-arkansas.html.

7. Edwards v. Aguillard. 1987. 482 United States Supreme Court Reports 578.

8. Dover trial transcripts. American Civil Liberties Union of Pennsylvania. http://www.aclupa. org/legal/legaldocket/intelligentdesigncase/ dovertrialtranscripts.htm.

9. Davis, P., and Kenyon, D.H. 1989. Of pandas and people: the central question of biological origins. Haughton Publishing Co. Dallas, Texas, USA. 160 pp.

10. Brazeau, M.D., and Ahlberg, P.E. 2006. Tetrapodlike middle ear architecture in a Devonian fish. Nature. 439:318-321.

11. Center for Science and Culture. The Wedge Strategy. http://www.antievolution.org/features/wedge.html.
12. Kitzmiller v. Dover Area School District. 2005. 04-CV2688. 2005 WL 578974 (M.D. Pa. 2005).

13. Nesse, R.M., Stearns, S.C., and Omenn, G.S. 2006. Medicine needs evolution. Science. 311:1071.

14. Loconte, J. 2005 December 21. Intelligent design has a place in the classroom. All things considered.

15. Chang, K. 2006 February 21. Few biologists but many evangelicals sign anti-evolution petition. The New York Times. F2.

16. Cox, M.M. 2005 August 29. Intelligent design is a threat, not a theory. Wisconsin State Journal. A6.

17. Science Education Protection Act. LRB-2463. http://www.legis.state.wi.us/assembly/asm76/ news/evolution.html.

18. Orwell, G., Orwell, S., and Angus, I. 2000. What is science? In George Orwell: the collected essays, journalism and letters. Volume 1. An age like this: 1920-1940. Nonpareil Books. Boston, Massachusetts, USA. 600 pp. 